\title{
Effects of Human Capital Expenditures on Non-Oil Sector Growth in the Republic of Congo
}

\author{
Christelle Inès Leticia Ndombi Ondze \\ Marien Ngouabi University of Brazzaville, Brazzaville, Republic of the Congo \\ Email: christelle.ndombiondze@umng.cg
}

How to cite this paper: Ndombi Ondze, C. I. L. (2021). Effects of Human Capital Expenditures on Non-Oil Sector Growth in the Republic of Congo. Modern Economy, 12, 1748-1767.

https://doi.org/10.4236/me.2021.1212089

Received: October 4, 2021

Accepted: December 3, 2021

Published: December 6, 2021

Copyright $\odot 2021$ by author(s) and Scientific Research Publishing Inc. This work is licensed under the Creative Commons Attribution International License (CC BY 4.0).

http://creativecommons.org/licenses/by/4.0/

(c) (i) Open Access

\begin{abstract}
This paper explores the relationship between human capital spending and non-oil sector growth in one direction only: from spending to non-oil sector growth. Using the theoretical framework developed by Knowles and Owen (1995), this study shows that spending does not influence non-oil sector growth. This result was obtained by estimating an Autoregressive Distributed Lag (ARDL) process. The data used were extracted from the World Bank's databases and are annual (1996 to 2018). We used several indicators of development in the world and a governance indicator among those designed by Kaufmann et al. (2005). From a theoretical point of view, this result does not support the theory of endogenous growth. On the other hand, it is an empirical contribution to the literature that exists to date on the causes of non-oil sector growth in Congo. Moreover, an economic policy implication has been formulated on the basis of this result.
\end{abstract}

\section{Keywords}

Public Expenditure on Health, Public Expenditure on Education, Non-Oil Sector Growth, Republic of the Congo, ARDL Process

\section{Introduction}

Currently, difficulties in the non-oil sector (decline in activities on the order of $7.9 \%$, reduction in business turnover, layoffs, etc.) are hindering economic growth in Republic of the Congo. Indeed, in a context marked by the fall in the price of a barrel of oil, one would expect the non-oil sector to constitute an essential link in cushioning this shock and, at the same time, in reviving economic activity.

Overall, several economic factors in addition to traditional factors (labor and capital) can be proposed to explain the malaise of this sector. In relation to the 
literature dedicated to economic growth, in a strict sense, we can mention foreign direct investment (Nistor, 2014; Silajdzic \& Mehic, 2015; Sokang, 2018), human capital (Bloom et al., 2004; Arabi \& Abdalla, 2013) and governance (Bhattacharjee \& Haldar, 2015 and Samarasinghe, 2018). These authors found a positive relationship between these variables and economic growth. In other words, weaknesses in any of these variables can result in slower or lower economic growth.

Since these arguments are true for growth in the broad sense, it is useful to determine whether they are also true for the non-oil sector. However, since the idea here is not to analyze the causal link between each of these factors and nonoil growth, we focus on human capital, seen through the prism of spending, as our theme indicates. This option is because, to our knowledge, the relationship between human capital expenditure and growth in this sector has hardly been the subject of any empirical work in Congo. By contrast, there is work on poverty and human capital (Mboko, 2015) on the one hand and human capital and happiness (Ngakala, 2018) on the other. Our contribution concerns the fact that particular emphasis is placed on the non-oil sector, which is an essential pillar of the diversification of the Congolese economy. In fact, in its NDP (2018-2022), this sector is one of the priority areas for achieving the sustainable development objectives, with agriculture in the broad sense as a lever. Moreover, the relationship between human capital spending and non-oil sector growth gives rise to concerns in terms of health, education, and governance.

1) In terms of health, in Republic of the Congo, despite initiatives taken by the Congolese authorities [health for all strategy (SSP) in 1978, development of the health plan (PNDS) between 1992 and 1996...], the country is facing innumerable health problems. According to the strategic plan for tobacco control in the Congo (2011-2015), life expectancy at birth was estimated at 51.9 years in 2005, and general mortality was estimated at 14 deaths per 1000. The 2005 Demographic and Health Survey (DHS) revealed that mortality rates are lower in urban areas than in rural areas. According to the strategic plan for tobacco control in the Congo (2011-2015), life expectancy at birth was estimated at 51.9 years in 2005 , and general mortality was estimated at 14 deaths per 1000 . The Demographic and Health Survey (DHS) conducted in 2005 revealed that mortality rates are lower in urban areas than in rural areas. The former is better equipped with basic social structures (drinking water, latrines, and health structures) than the latter. Under these conditions, can we assume that the weaknesses of the non-oil sector stem from the level of spending in the health sector?

2) In terms of education in Republic of the Congo, education for all has been considered a priority up to the Sustainable Development Goals (SDGs). In this regard, efforts made by the authorities are reflected in the quantitative dynamics of the Congolese education system (since the end of the troubled period of 1998 and 1999), which has resulted in a gross enrollment rate (GER) of more than $100 \%$, school access rate of approximately $95 \%$ and completion rate of approx- 
imately 73\% (CNSEE, 2017). However, the education and training system is inadequate to promote employment, as it is not oriented toward entrepreneurship (Education Sector Strategy 2015-2025). Therefore, could the weakness of the non-oil sector be due to spending in the education sector?

3) In terms of governance, a reading of global governance indicators (citizen voice and accountability, political stability and absence of violence, government effectiveness, regulatory quality, rule of law, and control of corruption) reveals that these are all negative for the case of Congo. This state of affairs assumes the existence of corruption (with all its corollaries). Thus, in an environment where governance is a problem, can spending on health and education drive growth in the non-oil sector?

All of these concerns lead to the following central question: Does human capital spending explain the growth of the non-oil sector? The objective of this paper is to analyze the effect of human capital expenditures on non-oil sector growth. In this work, we assume that human capital expenditures have positive effects on the growth of this sector.

The main limitation of this work concerns human capital expenditures, as we have used only two components of human capital (education and health), whereas human capital also takes into account welfare.

The second limitation is that structural phenomena such as Covid-19 are not taken into account due to data availability.

Apart from the introduction and conclusion, this article includes the following: 1) theoretical and empirical aspects of the relationship between human capital expenditure and non-oil sector growth, 2) methodological framework, 3) estimation procedure, and 4) presentation, interpretations, and discussion of results.

\section{Theoretical and Empirical Aspects of the Relationship between Human Capital Expenditure and Non-Oil Sector Growth}

In this section, we review some previous theoretical and empirical explanations of the relationship between human capital expenditures and economic growth. In doing so, we aim to identify the theoretical framework and econometric instruments that can be applied to the non-oil sector using data from Congo.

The theoretical explanations can be divided into three groups. In the first group, the central idea is that education is an important factor for economic growth in the sense that a skilled labor force can be a guarantee of productivity and thus of growth support at the firm or country level. This idea is shared by authors such as Lucas (1988), Römer (1990), and Tamura (1991). Thus, spending on education can enable states to have quality training centers and resource persons toward its progress.

On the other hand, in the second group, authors such as Grossman (1998) and Gillis et al. (1996) believe that improving health status increases the productive 
capacity of individuals. In other words, by increasing the workforce and endurance of workers, good health can contribute to an increase in the volume of production within a company or a country. Here, therefore, health expenditures can help to ensure that health care facilities and quality health personnel are available to support the main actors in economic activity, namely, consumers and producers.

In the third group, there is no direct relationship between investment and growth. Investment contributes to the economic growth of a country if it has a given level of human capital capable of absorbing new technologies. In other words, the development of human capital is a necessary condition for investment to stimulate growth. This idea is shared by Borensztein et al. (1998) in the context of FDI.

As far as empirical explanations are concerned, we have explanations relating to education and growth on the one hand and to health and growth on the other. Moreover, the authors who report on these explanations are numerous and can be divided into two groups: those who conducted studies in developed countries and those who focused on developing countries. In the context of this work, we are only interested in the second group.

Thus, for the relationship between education and growth, we begin by citing Mekdad \& Monir (2014), who studied the effect of public spending on education on economic growth in Algeria from 1974-2012. Using an error correction model, these authors arrived at an empirical result that supports the main hypothesis of their study that public spending on education positively affects economic growth in Algeria.

For her part, Owusu-Nantwi (2015) also examined the relationship between education spending and economic growth, but in Ghana. After estimating a vector error correction model from time series for the period 1970 to 2012, he found as an empirical result that education contributes significantly to the long-term growth of the Ghanaian economy.

Similarly, Sunde (2017) in Mauritius applied a Granger causality test to data from 1976 to 2016 obtained from the World Bank. In terms of output, he found that investment in education promotes economic growth. In contrast to previous authors, Kouton (2018) provided evidence of a negative long-run effect of public spending on education on economic growth (in Côte d'Ivoire) for the period 1970-2015. These results were obtained through the application of a Toda Yamamoto (1995) causality test and the estimation of an ARDL process.

For the relationship between health and growth, Piabuo and Tieguhong (2017) conducted a comparative analysis of the impact of health spending between countries in the CEMAC subregion and five other African countries that achieved the Abuja Declaration. The data for this study were extracted from the World Development Report (2016) database. Panel ordinary least squares (OLS), fully modified ordinary least squares (FMOLS), and dynamic ordinary least squares (DOLS) were used as the econometric analysis techniques. The results showed 
that health spending has a positive effect on economic growth in both samples.

Sarpong et al. (2018), on the other hand, examined the effects of health on long-term economic growth in 35 selected sub-Saharan African (SSA) countries using panel data covering the period 1997-2016. The data were analyzed using panel cointegration tests, Granger causality tests, and the dynamic OLS estimator. The results showed that healthy human capital is an important determinant of long-term economic growth in sub-Saharan Africa. Specifically, a percentage increase in health capital provided by per capita health expenditures increased growth by $0.207 \%$.

Similar to these two authors, Sahnoun (2018) explored the interaction between health spending and economic growth. After estimating a vector error correction model using data from 1980-2014, he found that in Tunisia, health spending had a positive influence on economic growth. By contrast, Udeorah et al. (2018) examined the impact of health spending on economic growth in Nigeria for the period 1980-2016. The data used in their study came from the Central Bank of Nigeria (CBN) statistical bulletin. Their study used real gross domestic product as the dependent variable, health spending as the main independent variable, and education spending as the control regressor to enhance the explanatory power of the model. The results of the dynamic panel model estimation using the generalized method of moments revealed that health spending had no impact on economic growth.

For the relationship between FDI and economic growth under the human capital constraint, Ekodo et al. (2020) assessed the effect of human capital on the relationship between foreign direct investment (FDI) and economic growth in the countries of the Economic and Monetary Community of Central Africa (CEMAC) using econometric estimates based on the generalized method of moments (GMM) in a dynamic panel of the six countries of the zone over the period from 1996 to 2016. The results show that human capital has no influence on the relationship between FDI and economic growth in the case of CEMAC countries and that almost all of these countries face a human capital quality problem instead.

From this review of the literature, it emerges that on the theoretical level, the authors are unanimous on the fact that human capital promotes economic growth. On the other hand, empirically, the results obtained are divergent. In other words, the debate is not yet over. Therefore, focusing on the growth of the non-oil sector in the context of this controversy can provide additional information. Thus, we opt to apply an ARDL process to Republic of the Congo data. That is, we plan to provide empirical evidence of a possible relationship between human capital expenditure and non-oil sector growth. In this approach, we aim to link the quality of human resources to the performance of all other sectors of activity other than the hydrocarbon sector, which contributes more than $50 \%$ of the national wealth. 


\section{Methodological Framework}

\subsection{Theoretical Model}

For this work, we opt for the theoretical model developed by Knowles and Owen (1995). The specificity of this model lies in its consideration of health as a human capital factor in the same way as education. Let us take the following Cobb-Douglass-type production function:

$$
Y=K^{\alpha} E^{\beta} H^{\gamma}(A L)^{1-\alpha-\beta-\gamma}
$$

where $L$ is the labor factor, $A$ is technical progress, $H$ is human capital in terms of health, $E$ is education, $K$ is the capital factor, and $Y$ is economic growth, that is, the growth of the non-oil sector in our case. Note that

$$
0<\alpha, \beta, \gamma<1, \gamma+\beta+\alpha<1 \text {. }
$$

Compared to the approach proposed by Knowles and Owen (1995), we assume that $L$ and $A$ grow at rates $n$ and $g$, respectively. Therefore, we have the following two equations:

$$
\begin{aligned}
& L=L_{0} e^{n} \\
& A=A_{0} e^{n}
\end{aligned}
$$

By dividing Equation (a) by the number of actual work units, i.e., $A L$, we obtain the following equation:

$$
y=k^{\alpha} e^{\beta} h^{\gamma}
$$

Où

$$
k=\frac{K}{A L}, e=\frac{E}{A L}, h=\frac{H}{A L}, y=\frac{Y}{A L}
$$

From Equation (d), we derive the following relationship:

$$
\frac{Y}{L}=y A
$$

Applying the logarithm to this equation while replacing the variable $A$ with its expression from Equation (c) gives us

$$
\ln \left(\frac{Y}{L}\right)=\ln (y * A)=\ln (y)+\ln (A)=\ln (y)+\ln \left(A_{0}\right)+n
$$

For $k=\frac{K}{A L}, \log (k)=\log (K)-\log (A)-\log (L)$ soit $\frac{\dot{k}}{k}=\frac{\dot{K}}{K}+\frac{\dot{A}}{A}+\frac{\dot{L}}{L}$.

Therefore, the growth dynamics of the variable $k$ can be written as follows:

$$
\dot{k}=S_{k} * y-(n+g+\delta) k
$$

By analogy, the following applies to variables (h) and (e):

$$
\begin{gathered}
\dot{h}=S_{h} * y-(n+g+\delta) h \\
\dot{e}=S_{e} * y-(n+g+\delta) e
\end{gathered}
$$

where $\delta$ represents the rate of depreciation of physical capital, which is assumed 
to be constant over time. Substituting the equilibrium values of Equations (g), (h), and (i) into (d) and applying a log-linear transformation, we obtain the expression for steady state income per capita (Chakroun, 2012) or non-oil sector GDP per capita in our case:

$$
\ln (y)=\ln \left(A_{0}\right)+n+\frac{\alpha}{\theta} \ln \left(S_{k}\right)+\frac{\gamma}{\theta} \ln \left(S_{e}\right)+\frac{\beta}{\theta} \ln \left(S_{h}\right)-\left(\frac{1-\theta}{\theta}\right) \ln (n+g+\delta)
$$

In this equation, $\theta=1-\alpha-\beta-\gamma$ and $S_{k}, S_{e}$ and $S_{h}$ are the fractions of output invested in the accumulation of physical capital, human capital in the form of education, and human capital in the form of health, respectively.

\subsection{Study Variables, Statistical Analyses, and Data Sources}

1) Study Variables

GDP excluding oil: This is the gross domestic product of the non-oil sector, i.e., the gross domestic product that comes from trade, hotels, agriculture, manufacturing, and other services. In the model to be estimated, it plays the role of explained variable.

Health expenditures: They correspond to the proxy of the health component of human capital. This variable is present in the empirical work of authors such as Piabuo and Tieguhong (2017) and Sahnoun (2018). Moreover, it is our first variable of interest and is expressed as a percentage of GDP.

Education Expenditures. This variable refers to total spending by public authorities on behalf of the education sector. As in the work of Sunde (2017) and Kouton (2018), it serves as a variable of interest. Like health spending, it is expressed as a percentage of GDP.

Foreign Direct Investment (FDI): This is our first control variable and refers to the flow of investment that comes from the rest of the world (that Congo records). We find this variable in the work of authors such as Tshepo (2018) and Njangang et al. (2018).

Working population: This represents our second control variable. As a traditional factor of growth, it appears in the vast majority of works on economic growth. We can cite the work of Klasen and Lawson (2007). In our work, this population refers to people between the ages of 15 and 64 .

Control of corruption: This is the institutional variable in the empirical model below. It is found in the studies by Obamuyi and Olayiwola (2019).

In sum, the empirical model associated with Equation $(j)$ can be written as follows:

$$
\begin{aligned}
& \ln (\text { GDP excluding oil }) \\
& =a_{0}+a_{1} * \text { Health expenditures }+a_{2} * \text { Education Expenditures }+a_{3} * \ln (\text { FDI }) \\
& \quad+a_{4} * \text { Working population }+a_{5} * \text { Control of corruption }+\varepsilon
\end{aligned}
$$

\section{2) Statistical analysis}

Table 1 below provides a description of the variables used to model the effect of human capital on non-oil sector growth. 
Table 1. Descriptive statistics.

\begin{tabular}{ccccc}
\hline Variables & Moyenne & Ecart-type & Minimum & Maximum \\
\hline Pib hors pétrole & 1680.6 & 899.13 & 673 & 3131.3 \\
Dépenses de santé & $0.93 \%$ & $0.43 \%$ & $0.47 \%$ & $1.95 \%$ \\
Dépense d'éducation & $3.41 \%$ & $1.07 \%$ & $1.83 \%$ & $6.22 \%$ \\
Investissements directs étrangers & 941.91 & 1114.55 & -135.36 & 4278.11 \\
Population active & 55.31 & 0.39 & 54.26 & 55.84 \\
Contrôle de la corruption & -1.15 & 0.13 & -1.35 & -0.86 \\
\hline
\end{tabular}

Source: the author, based on data extracted from https://www.worldbank.databank.org/, 2018.

Table 1 shows that over the study period we selected, the average value of the GDP excluding oil amounts to 1680.60 million USD. Moreover, these values fluctuate between 673 and 3131.30 million USD. The standard deviation of 899.13 indicates that the values in this series are scattered around the mean. The health expenditure variable oscillates between 0.47 and 1.95 percent of GDP with a standard deviation of 0.43 (close to zero), which means that there is not a strong dispersion of the share of health expenditure around the average value of 0.93. For the variable Education expenditure, we observe that the values of the latter fluctuate between 1.83 and 6.22 percent of GDP and that the dispersion around the mean is not concentrated since the value of the standard deviation is not close to 0 , i.e., 1.07 percent. In addition, we can see that on average, the foreign direct investment (FDI) variable amounts to 941.91 million USD and that there is a dispersion around this average since the standard deviation is 1114.55 million USD. Moreover, the values of this variable range from -135.36 to 4278.11. Regarding the active population, i.e., people between 15 and 64 years of age, it appears that their number represents an average of $55.31 \%$ of the total population and that during the study period, their proportion fluctuated between $54.26 \%$ and $55.84 \%$. Finally, the values taken by the control of corruption were negative during the period 1996-2018. This supports the idea that public authorities are struggling to control corruption.

\section{3) Data source}

In this work, the frequency of data used is annual. Specifically, our series ran from 1996 to 2018 and came from the World Bank's World Development and Governance Indicators databases. The choice of this period is justified by the availability of data, in this case on the control of corruption, which is an institutional governance indicator developed by Kaufmann et al. (2005).

\subsection{Human Capital Expenditures and Non-Oil Sector Growth in Republic of the Congo: A Joint Overview}

This section is devoted to the presentation of the evolution of our explained variable (GDP excluding oil) and our variables of interest (health and education 
expenditures). Before proceeding, we provide a brief overview of the composition of the non-oil sector and some of Congo's education and health indicators.

With respect to the first point, Republic of the Congo is one of the countries in sub-Saharan Africa where the non-oil sector plays a relatively minor role in explaining national wealth. Indeed, the productive structure of the country is essentially based on the exploitation of oil, as noted by the Economic Commission for Africa (ECA, 2017). Pie Table 2 below gives us an idea on the configuration of this sector.

Table 2 shows that the "Mining and gas" sector is the driving force behind the non-oil sector. Next comes the "Trade, restaurants and hôtels" sector, followed by "Public administration," "Transport and telecommunications," and "Agriculture, livestock, fishing and hunting." Finally, the share of the components "Buildings and public works", "Manufacturing", "net taxes on products", "Forestry and logging" and "Electricity, gas" seems to be negligible, especially when looking at these sectors individually.

Second, investments in education and health figure prominently in the 20122016 Strategy for Growth, Employment and Poverty Reduction (SCERP). Previously, Congo developed an education sector strategy and a national health policy in the early 2000s. However, despite these documents, key education and health indicators remain weak.

On the one hand, it can be noted that spending to improve the health status of populations is insufficient in the sense that the total amount of spending dedicated to health (as a percentage of GDP) in 2013, for example, amounted to only $4.1 \%$. This is clearly low with reference to regional convergence criteria. Additionally, most household health expenditures are directed toward curative and not preventive care. On the other hand, the same source indicates that in relation to GDP, public spending on education rose from $1.8 \%$ in 2008 to $2.7 \%$ in 2012, well before reaching $4.4 \%$ in 2014. However, this upward trend remains weak compared to the results of countries such as Cameroon and Senegal over

Table 2. Composition of the non-oil sector.
1) Mining and gas
2) Trade, restaurants and hôtels
3) Public administration
4) Transport and telecommunications
5) Agriculture, fishing and hunting
6) Buildings and public works
7) Manufacturing
8) Net taxes on products
9) Forestry and logging
10) Electricity, gas

Source: Author, based on BEAC data, 2017. 
the same period. In addition, less than $50 \%$ of 6 th graders satisfactorily meet the competency goals (PASEC, 2014). This indicates poorer learning outcomes among elementary school graduates.

With the above in mind, we can then comment on the shape of each of the curves below.

The observation of Figure 1 shows us that the GDP excluding oil experienced an increase between 1999 and 2015 before falling slightly and then experiencing stability between 2016 and 2018. Health care spending, on the other hand, remained broadly stable between 1996 and 2012 despite peaks in 2001 and 2008 and troughs in 2009 and 2011. On the other hand, these expenditures have gradually increased over the last six years before 2018. Finally, except for the sharp spike in 2010, education spending as a whole visibly moved up and down over the 1996-2018 period.

The trend in health expenditure reflects the low level of resources allocated to the health sector despite the challenges to be met (access to health services for vulnerable groups, reduction of the overall burden of disease, development of specialized hospital care, etc.). This analysis is also valid for the education sector. However, the peak in 2010 is explained by the achievement of the Heavily Indebted Poor Countries Initiative (HIPC) completion point, which allowed the country to substantially reduce its external debt and boost the education sector. The timid evolution of the non-oil sector indicates the existence of a Dutch disease and a low demand.

The visual examination we conducted suggests no correlation between non-oil GDP and our variables of interest (education and health spending). However, to confirm or deny this impression, we then conducted a correlation test between these variables. The results are shown in Table 3 below.

Table 3 shows that the correlation coefficients between non-oil GDP and each variable of interest are positive and significant at the $1 \%$ level. In other words, there is a presumption of a statistical link between these variables and our dependent variable. Therefore, it seems useful to investigate whether there is a causal relationship between "GDP excluding oil" and the variables "health expenditure" and "education expenditure."

Table 3. Matrix of correlation coefficients.

\begin{tabular}{cccc}
\hline $\begin{array}{c}\text { Coefficient de } \\
\text { correlation Probabilité }\end{array}$ & Ln(GDP exclusion oil) & $\begin{array}{c}\text { Education } \\
\text { expenditure }\end{array}$ & $\begin{array}{c}\text { Health } \\
\text { expenditures }\end{array}$ \\
\hline Ln (GDP excluding oil) & 1.00 & & \\
Education expenditure & - & 1.00 & \\
& $0.743^{*}$ & - & 1.00 \\
Health expenditure & 0.000 & 0.560 & - \\
\hline
\end{tabular}

Source: Author, using data from https://www.worldbank.databank.org/, 2018. * significant at the threshold $1 \%$. 


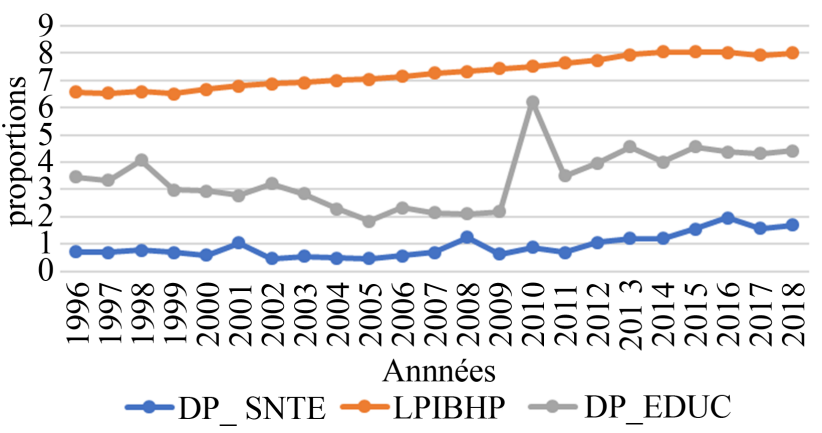

Figure 1. Trends in health and education spending and non-oil GDP. Source: the authors, based on data extracted from https://www.worldbank.databank.org/, 2018.

\section{Estimation Procedure}

This section is devoted to the presentation of the different steps leading to the estimation of the relationship between human capital and growth in the non-oil sector. More precisely, it is first the study of the stationarity of the series and then the justification and overview of the ARDL process.

\section{1) Stationarity of variables}

Table 4 provides information on the level of integration of the variables that we have chosen to model the effects of human capital on the growth of the non-oil sector. These results were obtained after applying the Phillips and Perron and Kwiatkowski, Phillips, Schmidt, and Shin tests, which correct for the problems (of breaks and error autocorrelation) that often occur in chronicles.

Table 4 shows that all our series are stationary in first difference. Therefore, we can retain a staggered lag autoregressive model (ARDL) to estimate the empirical model associated with Equation (j) that we specify below.

2) Why an autoregressive model with staggered lags?

Apart from the level of integration of all our series, three other points justify the use of this model: a) the possibility of having short- and long-term results that this model offers, b) the ability of this model to involve lags on the explained variable and the explanatory variables, and c) the fact that this model fits well with small sample sizes, i.e., 23 observations in our case. Moreover, this model allows us to correct the problems of endogeneity and correlation of errors by considering the lagged variables as regressors. In general, the simplest functional form of this model is the following:

$$
z(t)=\partial+\delta y(t)+\mu(t)
$$

\section{3) ARDL model estimation technique}

This model is estimated using the ordinary least squares (OLS) method. However, to obtain long-term results, it is necessary to integrate the Fisher statistic. Note that the F-test is performed to signify the lagged levels of the variables in the unrestricted error correction form of the ARDL model. This error correction model is specified as follows:

$$
D y(t)=\alpha_{0} \sum_{i=1}^{p} \delta_{i} D y_{t-i}+\sum_{i=1}^{p} \gamma_{i} D x_{t-i}+\beta_{1} y_{t-1}+\beta_{2} x_{t-1}+\varepsilon_{t}
$$


Table 4. Unit root test results.

\begin{tabular}{cc}
\hline Variables & Ordre d'intégration \\
\hline GDP excluding oil & 1 \\
Health expenditure & 1 \\
Education expenditure & 1 \\
Foreign direct investment & 1 \\
Working population & 1 \\
Control of corruption & 1 \\
\hline
\end{tabular}

Source: Author, using data extracted from https://www.worldbank.databank.org/, 2018 and Eview9 software.

$\delta$ and $\gamma$ represent the short-term dynamics, $\beta_{1}$ and $\beta_{2}$ indicate the long-term relationship, and $\varepsilon$ is the error term of the white noise. The null hypothesis of the F-test means that the cointegrating relationship between the variables does not exist:

$$
\left\{\begin{array}{l}
H_{0}: \beta_{1}=\beta_{2}=0 \\
H_{1}: \beta_{1} \neq \beta_{2} \neq 0
\end{array}\right.
$$

The asymptotic distribution of the F-statistic is not standard. In other words, it depends on the number of regressors and the order of integration of the explanatory variables. To determine the optimal number of delays in the ARDL process, information criteria such as Akaike (AIC) and Schwartz (SBC) are used.

\section{Presentation, Interpretation and Discussion of Results}

In this section, we focus on the following points: the optimal process, tests of autocorrelation of residuals, cointegration, stability, and short- and long-term results.

1) Optimal process

Table 5 shows all of the estimable models that generate less information loss in their implementation.

Consideration of this graph reveals that of all the models presented, twenty in total, the ARDL model $(1,1,0,1,0,1)$ has the least amount of information lost.

\section{2) Test d'autocorrélation des erreurs}

Table 6 below provides information on the behavior of the residuals obtained from the estimation of the ARDL model $(1,1,0,1,0,1)$.

It can be seen from Table 6 that the probabilities associated with the Q-stat statistic are all greater than 0.05 . This implies that the residuals of this model form white noise. In other words, the residuals are not linked by a replication process.

\section{3) Cointegration test}

To determine if our different series maintain a long-term relationship, we opt for the cointegration test designed by Pesaran and Shin (1999). The results of the application of this test are reported in Table 7. 
Table 5. Top 20 ARDL models.

\begin{tabular}{|c|c|c|c|c|c|c|}
\hline Model & $\log L$ & $\mathrm{AIC}^{\star}$ & $\mathrm{BIC}$ & HQ & Adj. R-sq & Specification \\
\hline 11 & 36.346066 & -3.099537 & -2.609412 & -3.050818 & 0.993240 & $\begin{array}{c}\text { ARDL } \\
(1,1,0,1,0,1)\end{array}$ \\
\hline 3 & 36.643842 & -3.016923 & -2.477785 & -2.963331 & 0.992385 & $\begin{array}{c}\text { ARDL } \\
(1,1,1,1,0,1)\end{array}$ \\
\hline 27 & 34.421002 & -2.990706 & -2.549593 & -2.946859 & 0.992581 & $\begin{array}{c}\text { ARDL } \\
(1,0,0,1,0,1)\end{array}$ \\
\hline 9 & 36.406685 & -2.989022 & -2.449884 & -2.935430 & 0.992169 & $\begin{array}{c}\text { ARDL } \\
(1,1,0,1,1,1)\end{array}$ \\
\hline 12 & 34.302600 & -2.976777 & -2.535664 & -2.932929 & 0.992477 & $\begin{array}{c}\text { ARDL } \\
(1,1,0,1,0,0)\end{array}$ \\
\hline 28 & 33.286736 & -2.974910 & -2.582810 & -2.935935 & 0.992464 & $\begin{array}{c}\text { ARDL } \\
(1,0,0,1,0,0)\end{array}$ \\
\hline 25 & 35.197953 & -2.964465 & -2.474340 & -2.915746 & 0.992262 & $\begin{array}{c}\text { ARDL } \\
(1,0,0,1,1,1)\end{array}$ \\
\hline 26 & 33.754201 & -2.912259 & -2.471146 & -2.868411 & 0.991976 & $\begin{array}{c}\text { ARDL } \\
(1,0,0,1,1,0)\end{array}$ \\
\hline 1 & 36.657210 & -2.900848 & -2.312698 & -2.842385 & 0.990876 & $\begin{array}{c}\text { ARDL } \\
(1,1,1,1,1,1)\end{array}$ \\
\hline 4 & 34.585607 & -2.892424 & -2.402299 & -2.843705 & 0.991684 & $\begin{array}{c}\text { ARDL } \\
(1,1,1,1,0,0)\end{array}$ \\
\hline 19 & 34.572495 & -2.890882 & -2.400756 & -2.842162 & 0.991671 & $\begin{array}{c}\text { ARDL } \\
(1,0,1,1,0,1)\end{array}$ \\
\hline 20 & 33.461423 & -2.877815 & -2.436702 & -2.833967 & 0.991695 & $\begin{array}{c}\text { ARDL } \\
(1,0,1,1,0,0)\end{array}$ \\
\hline 10 & 34.343536 & -2.863945 & -2.373820 & -2.815226 & 0.991444 & $\begin{array}{c}\text { ARDL } \\
(1,1,0,1,1,0)\end{array}$ \\
\hline 17 & 35.199996 & -2.847058 & -2.307920 & -2.793467 & 0.990975 & $\begin{array}{c}\text { ARDL } \\
(1,0,1,1,1,1)\end{array}$ \\
\hline 18 & 33.765455 & -2.795936 & -2.305810 & -2.747216 & 0.990842 & $\begin{array}{c}\text { ARDL } \\
(1,0,1,1,1,0)\end{array}$ \\
\hline 2 & 34.611442 & -2.777817 & -2.238679 & -2.724225 & 0.990328 & $\begin{array}{c}\text { ARDL } \\
(1,1,1,1,1,0)\end{array}$ \\
\hline 30 & 29.830502 & -2.568294 & -2.176194 & -2.529319 & 0.988683 & $\begin{array}{c}\text { ARDL } \\
(1,0,0,0,1,0)\end{array}$ \\
\hline 29 & 30.779756 & -2.562324 & -2.121211 & -2.518477 & 0.988614 & $\begin{array}{c}\text { ARDL } \\
(1,0,0,0,1,1)\end{array}$ \\
\hline 22 & 30.161590 & -2.489599 & -2.048486 & -2.445751 & 0.987755 & $\begin{array}{c}\text { ARDL } \\
(1,0,1,0,1,0)\end{array}$ \\
\hline 24 & 29.079446 & -2.479935 & -2.087834 & -2.440959 & 0.987638 & $\begin{array}{c}\text { ARDL } \\
(1,0,1,0,0,0)\end{array}$ \\
\hline 21 & 31.011648 & -2.471959 & -1.981833 & -2.423239 & 0.987338 & $\begin{array}{c}\text { ARDL } \\
(1,0,1,0,1,1)\end{array}$ \\
\hline
\end{tabular}




\section{Continued}

\begin{tabular}{|c|c|c|c|c|c|c|}
\hline 14 & 29.846004 & -2.452471 & -2.011358 & -2.408624 & 0.987292 & $\begin{array}{c}\text { ARDL } \\
(1,1,0,0,1,0)\end{array}$ \\
\hline 13 & 30.781421 & -2.444873 & -1.954748 & -2.396154 & 0.986990 & $\begin{array}{c}\text { ARDL } \\
(1,1,0,0,1,1)\end{array}$ \\
\hline 8 & 29.659649 & -2.430547 & -1.989434 & -2.386699 & 0.987010 & $\begin{array}{c}\text { ARDL } \\
(1,1,1,0,0,0)\end{array}$ \\
\hline 23 & 29.505351 & -2.412394 & -1.971281 & -2.368547 & 0.986772 & $\begin{array}{c}\text { ARDL } \\
(1,0,1,0,0,1)\end{array}$ \\
\hline 7 & 30.409249 & -2.401088 & -1.910963 & -2.352369 & 0.986408 & $\begin{array}{c}\text { ARDL } \\
(1,1,1,0,0,1)\end{array}$ \\
\hline 6 & 30.198223 & -2.376261 & -1.886136 & -2.327542 & 0.986066 & $\begin{array}{c}\text { ARDL } \\
(1,1,1,0,1,0)\end{array}$ \\
\hline 5 & 31.115739 & -2.366558 & -1.827419 & -2.312966 & 0.985407 & $\begin{array}{c}\text { ARDL } \\
(1,1,1,0,1,1)\end{array}$ \\
\hline 32 & 27.024214 & -2.355790 & -2.012702 & -2.321686 & 0.985831 & $\begin{array}{c}\text { ARDL } \\
(1,0,0,0,0,0)\end{array}$ \\
\hline 31 & 27.379560 & -2.279948 & -1.887848 & -2.240973 & 0.984901 & $\begin{array}{c}\text { ARDL } \\
(1,0,0,0,0,1)\end{array}$ \\
\hline 16 & 27.289692 & -2.269376 & -1.877275 & -2.230400 & 0.984741 & $\begin{array}{c}\text { ARDL } \\
(1,1,0,0,0,0)\end{array}$ \\
\hline 15 & 27.830020 & -2.215296 & -1.774184 & -2.171449 & 0.983891 & $\begin{array}{c}\text { ARDL } \\
(1,1,0,0,0,1)\end{array}$ \\
\hline
\end{tabular}

Source: Author, based on data extracted from https://www.worldbank.databank.org/, 2018 et the logiciel Eview9.

Table 6. Correlogram of residues.

\begin{tabular}{|c|c|c|c|c|c|c|}
\hline Autocorrelation & Partial Correlation & & $\mathrm{AC}$ & PAC & Q-Stat & $\operatorname{Prob}^{*}$ \\
\hline$\cdot 1^{* *} \cdot \mid$ & $\left.\cdot\right|^{* *} \cdot \mid$ & 1 & 0.320 & 0.320 & 2.0735 & 0.150 \\
\hline$\cdot{ }^{*}||$. & $\cdot{ }^{*}||$. & 2 & -0.068 & -0.190 & 2.1731 & 0.337 \\
\hline$\cdot{ }^{\star}||$. & $\cdot{ }^{\star}||$. & 3 & -0.167 & -0.093 & 2.8190 & 0.420 \\
\hline$\cdot{ }^{*}||$. & $\cdot{ }^{*}||$. & 4 & -0.173 & -0.108 & 3.5586 & 0.469 \\
\hline.$||$. &.$|\cdot|$ & 5 & -0.044 & 0.023 & 3.6106 & 0.607 \\
\hline.$|\cdot|$ &.$||$. & 6 & 0.030 & -0.009 & 3.6362 & 0.726 \\
\hline.$|\cdot|$ & $\cdot{ }^{*}||$. & 7 & -0.057 & -0.116 & 3.7396 & 0.809 \\
\hline.$|\cdot|$ &.$|\cdot|$ & 8 & -0.007 & 0.041 & 3.7415 & 0.880 \\
\hline$\cdot{ }^{*}|\cdot|$ & $\cdot{ }^{*}|\cdot|$ & 9 & -0.074 & -0.118 & 3.9651 & 0.914 \\
\hline$\cdot{ }^{*}||$. &.$|\cdot|$ & 10 & -0.101 & -0.063 & 4.4356 & 0.926 \\
\hline$\cdot{ }^{*}||$. & $\cdot{ }^{*}|\cdot|$ & 11 & -0.124 & -0.132 & 5.2658 & 0.918 \\
\hline.$||$. &.$|\cdot|$ & 12 & -0.014 & 0.036 & 5.2781 & 0.948 \\
\hline
\end{tabular}

Source: Author, using data extracted from https://www.worldbank.databank.org/, 2018 and Eview9 software. 
Table 7. Bounds test results.

\begin{tabular}{ccc}
\hline Test statistic & Valeur & $\mathrm{K}$ \\
\hline F-statistic & 6.38 & 5 \\
& Valeurs critique de Bounds & \\
Seuil de significativité & Borne inférieure & Borne supérieure \\
$10 \%$ & 2.08 & 3 \\
$5 \%$ & 2.39 & 3.38 \\
$2.5 \%$ & 2.70 & 3.73 \\
$1 \%$ & 3.06 & 4.15 \\
\hline
\end{tabular}

Source: Author, using data extracted from https://www.worldbank.databank.org/, 2018 and Eview9 software.

From Table 7, we see that the Fischer statistic is equal to 6.38 . This value is higher than the upper bounds of all the significance levels, so we conclude that our series converges in the long run.

\section{4) Stability test}

The following representation provides information on the behavior of the estimated model over time (Figure 2).

Considering this graph, we can see that the Cusum curve is within the confidence interval. Therefore, we can say that the estimated model is stable over time.

\section{5) Short and long term results}

Table 8 and Table 9 below deal with the short- and long-term outputs of the ARDL model estimation $(1,1,0,1,0,1)$.

Table 8 reveals that none of our variables of interest explains the growth of the non-oil sector. On the other hand, the coefficient associated with the "control of corruption" variable has the expected sign and is significant at the $1 \%$ level.

Table 9 shows that the long-term results are identical to the short-term results. The only difference is that in this time horizon, the active population variable is significant at the $1 \%$ threshold.

\section{6) Robustess}

In sum, the short- and long-term models have satisfactory properties: a) uncorrelated residuals, b) existence of a long-run relationship, c) stable model over time, and d) negative recall force, less than unity and significant at the $1 \%$ threshold. We can then proceed to the interpretation of the outputs of our estimation.

The outputs from the estimation of the model on the relationship between human capital expenditure and non-oil sector growth allow us to draw one main lesson: Human capital expenditure is a negligible factor in explaining the growth of the non-oil sector in Republic of the Congo. 


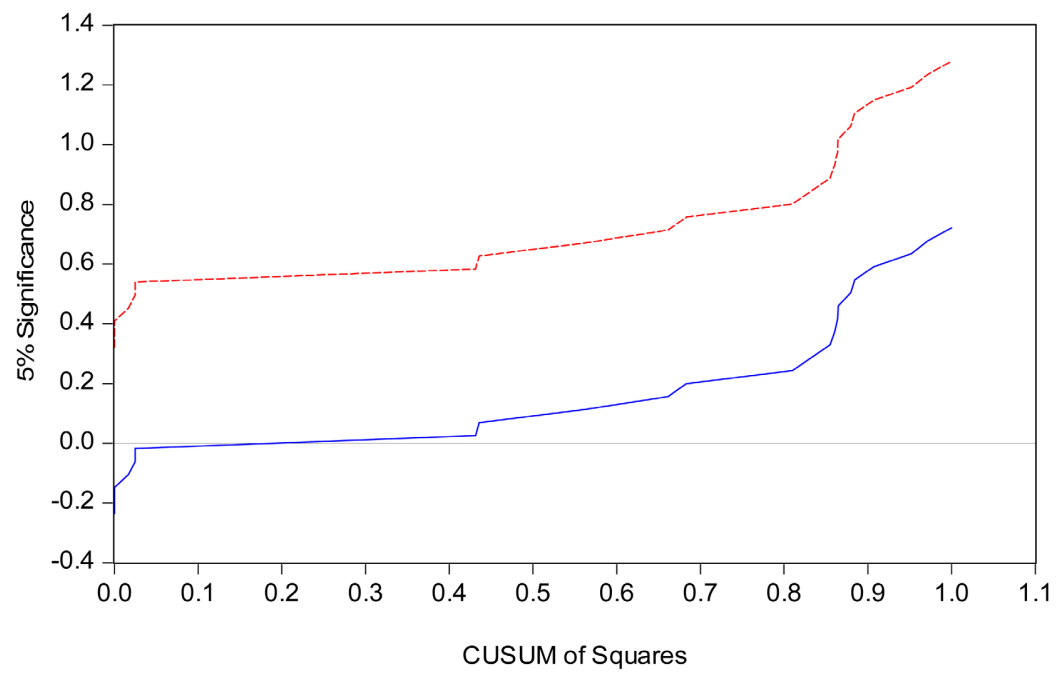

Figure 2. Result of Cusum test. Source: Author, using data extracted from https://www.worldbank.databank.org/, 2018 and Eview9 software. The red line is the confidence line of the significance of the cusum test. The blue line indicates the cusum line.

Table 8. Short-term results.

\begin{tabular}{ccccc}
\hline Variables & Coefficients & Std Error & t-Statisc & Prob \\
\hline$D$ (Dépenses d'éducation $)$ & 0.005 & 0.007 & 0.736 & 0.485 \\
$D$ (Dépenses de santé) & -0.026 & 0.035 & -0.750 & 0.477 \\
$D($ In(investissement directs étrangers $)$ & 0.005 & 0.005 & 0.871 & 0.412 \\
$D($ Population active $)$ & $0.142^{*}$ & 0.076 & 1.852 & 0.106 \\
$D($ Contrôle de la corruption $)$ & $-0.552^{*}$ & 0.093 & -5.926 & 0.000 \\
CointE $(-1)$ & $-0.231^{\star}$ & 0.027 & -8.459 & 0.000 \\
\hline
\end{tabular}

Source: Author, using data from https://www.worldbank.databank.org/, 2018 and Eview9 software ${ }^{*}$ significant at the $1 \%$ threshold.

Table 9. Résultats de long terme.

\begin{tabular}{ccccc}
\hline Variables & Coefficients & Std Error & $t$-Statisc & Prob \\
\hline Dépenses d'éducation & 0.135 & 0.06 & 2.117 & 0.072 \\
Dépenses de santé & -0.187 & 0.382 & -0.491 & 0.638 \\
In (investissement directs étrangers) & 0.170 & 0.094 & 1.799 & 0.114 \\
Population active) & $0.666^{*}$ & 0.218 & 3.045 & 0.018 \\
Contrôle de la corruption & $-3.266^{*}$ & 1.171 & -2.788 & 0.026 \\
\hline
\end{tabular}

Source: Author, using data from https://www.worldbank.databank.org/, 2018 and Eview9 software ${ }^{*}$ significant at the $1 \%$ threshold.

Human capital expenditure: A negligible factor in explaining the growth of the non-oil sector. 
According to our econometric approach, this lesson is based precisely on the nonsignificance of our two variables of interest (health and education expenditures) in both the short and long term. Indeed, Table 8 and Table 9 show us that the coefficients associated with these variables are not significant since at the threshold considered (5\%) the probabilities attributed to them are greater than 0.05. On the other hand, it appears that the "control of corruption" hinders the growth of this sector, whereas the "active population" or demography constitutes a lever.

If we replace broad economic growth with growth in the non-oil sector, we can say that this result runs opposite to our theoretical development and invalidates the hypothesis of this work. Moreover, it agrees with that obtained by Udeorah et al. (2018) for the case of the health component. However, opposes the findings of the work of Sunde (2017), Kouton (2018), and many other authors in the case of education. In relation to our field of study, we can explain this result by the following points: 1) low level of spending on health and education, 2) high dependence on the non-oil sector and the oil sector, and 3) weak governance.

The current low level of spending on health and education, which is less than $5 \%$ for each type of expenditure, does not encourage the development of human capital; insofar as with such shares, it is difficult for the authorities in charge of these issues to promote the education of the Congolese in its entirety, including the civic, moral, and physical aspects. Therefore, it is important to have, on the one hand, the basic skills necessary to carry out its industrialization strategy due to the near nonexistence of vocational education and, on the other hand, well-equipped agents to effectively use public resources (ADB, 2012). This reality therefore supports the assertion that variations in "non-oil GDP" do not truly depend on human capital but rather on other realities such as the oil sector and the quality of institutions, as explained in the following paragraphs.

In Congo, economic performance is structurally dependent on the hydrocarbon sector. For example, the country's growth in 2014, before the crisis, was largely driven by a $3.1 \%$ increase in oil production. In such a configuration, a drop in the price of oil can result in a decline in the growth of the non-oil sector by reducing the profit margin or closing companies in this sector (due to the weak demand for goods and services in trade, hotels, transport and telecommunications, etc., that this can generate). By analogy, a symmetric analysis concerns the case of a rise in the price of oil. Therefore, regardless of the characteristics (good or bad) of human capital, its place in the explanation of the non-oil sector scorecard can simply be questioned, as our results indicate.

With regard to governance, its role in explaining the lack of a causal link between human capital and non-oil GDP can be put into perspective through the execution of budgets (health and education). To this end, operating and investment budget execution rates are still below the norm for middle-income countries. This indicates the existence of losses due either to limited management of public resources or a lack of supervision of the development and implementa- 
tion of sector policies from these three pillars [Ministry of Primary, Secondary and Literacy Education (MEPSA), Ministry of Technical and Vocational Education, Skills Training and Employment (METPFQE), and Ministry of Higher Education (MES)]. These problems have implications for returns and thus for the ability of these sectors to influence the non-oil sector. Hence, there is a lack of interaction between the two dimensions of human capital and non-oil GDP.

\section{Conclusion}

Since the work of Lucas (1988), many authors (Arabi \& Abdalla, 2013; Pelinescu, 2015; Karambakuwa et al., 2019; Sharma, 2019) have become increasingly interested in the role of human capital in explaining the phenomenon of self-sustained growth. However, to date, there is almost no work that addresses this relationship in the context of non-oil sector growth, in this case in Congo. To fill this gap, we devoted this article to an analysis of the effect of human capital expenditures on the growth of the non-oil sector. After reviewing the theoretical debate and identifying some empirical works, our approach consisted of specifying the theoretical model designed by Knowles and Owen (1995) and then estimating the associated empirical model through an econometric technique that integrates stationary variables in level or in first difference in a cointegration relation. The result shows that human capital expenditure does not influence the growth of the non-oil sector. Thus, we can argue that the evolution of this sector is not significantly dependent on investments in health and education. On the other hand, oil activities and the quality of governance play a significant role in promoting this sector. Therefore, public authorities should place special emphasis on the professional training of workers in the non-oil sector and further strengthen institutions to achieve satisfactory performance in the diversification process.

\section{Conflicts of Interest}

The author declares no conflicts of interest regarding the publication of this paper.

\section{References}

ADB: African Development Bank (2012). Financial Statements.

Arabi, K. A. M., \& Abdalla, S. Z. S. (2013). The Impact of Human Capital on Economic Growth: Empirical Evidence from Sudan. Research in World Economy, 4, 43-45. https://doi.org/10.5430/rwe.v4n2p43

Bhattacharjee, \& Haldar (2015). Economic Growth of Selected South Asian Countries: Does Institution Matter? Asian Economic and Financial Review, 5, 356-370. https://doi.org/10.18488/journal.aefr/2015.5.2/102.2.356.370

Bloom, D. E. et al. (2004). The Effect of Health on Economic Growth: A Production Function Approach. World Development, 32, 1-13. https://doi.org/10.1016/j.worlddev.2003.07.002

Borensztein, E., De Gregorio, J., \& Lee, J.-W. (1998). How Does the Foreign Investment Affect Economic Growth? Journal of International Economics, 45, 115-135. 
https://doi.org/10.1016/S0022-1996(97)00033-0

Chakroun, M. (2012). Les effets non linéaires de la santé sur la croissance: Une investigation à l'aide d'un modèle à seuil. Revue Tunisienne d'Economie et de Gestion, 31, 121-151.

CNSEE: Centre National de la Statistique et des Etudes Economiques, November 2017.

Ekodo, R., Ndam, M., \& Ousmanou, K. (2020). Investissement direct étranger et croissance en zone CEMAC: Le rôle du capital humain. Revue Marocaine d'Économie, 3, 1-18.

Gillis, M., Perkins, D. H., Roemer, M., \& Snodgrass, D. R. (1996). Economics of Development. W. W. Norton \& Company.

Grossman, M. (1998). On Optimal Length of Life. Journal of Health Economics, 17, 499-509. https://ssrn.com/abstract $=3319224$ https://doi.org/10.1016/S0167-6296(97)00041-6

Karambakuwa, T., Ncwadi, R., \& Phiri, A. (2019). The Human Capital-Economic Growth Nexus in SSA Countries: What Can Strengthen the Relationship? MPRA Paper No. 95199. https://doi.org/10.1108/IJSE-08-2019-0515

Kaufmann, K., Mastruzzi, M., \& Kraay, A. (2005). Governance Matters IV: Governance Indicators for 1996-2004. World Bank. https://doi.org/10.2139/ssrn.718081

Klasen, S., \& Lawson, D. (2007). The Impact of Population Growth on Economic Growth and Poverty Reduction in Uganda.

Knowles, S., \& Owen, D. (1995). Health Capital and Cross-Country Variation in Income per Capita in the Mankiw-Romer-Weil Model. Economics Letters, 48, 99-106. https://doi.org/10.1016/0165-1765(94)00577-O

Kouton, J. (2018). Education Expenditure and Economic Growth: Some Empirical Evidence from Côte d'Ivoire. Journal of Economics and Sustainable Development, 14, 22-34.

Lucas (1988). On the Mechanics of Economic Development. Journal of Monetary Economics, 22, 3-42. https://doi.org/10.1016/0304-3932(88)90168-7

Masipa, T. S. (2018). The Relationship between Foreign Direct Investment and Economic Growth in South Africa: Vector Error Correction Analysis. Independent Research Journal in the Management Sciences, 18, a466. https://doi.org/10.4102/ac.v18i1.466

Mboko (2015). Pauvreté des ménages et éducation au Congo: Application d'un modèle de comptage à partir des données du RGPH2007 (56 p.). Observatoire démographique et statistique de l'espace francophone/Université Laval (Collection Rapport de recherche de l'ODSEF).

Mekdad, Y., Dahmani, A., \& Louaj, M. (2014). Public Spending on Education and Economic Growth in Algeria: Causality Test. International Journal of Business and Management, 2, 55-70.

Ngakala (2018). Effets de l'education sur le bonheur au Congo. Annales de l'Université Marien N'GOUABI, Sciences et Economiques et de Gestion, 18, 347-357.

Nistor (2014). FDI and Economic Growth, the Case of Romania. Procedia Economics and Finance, 15, 577-582. https://doi.org/10.1016/S2212-5671(14)00514-0

Njangang, H., Ndeffo, L. N., Noubissi, E., \& Koyeu, P. F. (2018). The Long-Run and ShortRun Effects of Foreign Direct Investment, Foreign Aid and Remittances on Economic Growth in African Countries.

Obamuyi, T. M., \& Olayiwola, S. O. (2019). Corruption and Economic Growth in India and Nigeria. Journal of Economics and Management, 35, 80-105.

https://doi.org/10.22367/jem.2019.35.05

Owusu-Nantwi, V. (2015). Education Expenditures and Economic Growth: Evidence from Ghana. Journal of Economics and Sustainable Development, 6, 69-77. 
PASEC (2014). Performance of Education Systems in French-Speaking Sub-Saharan Africa: Skills and Success Factors in Primary Education 2015.

Pelinescu, E. (2015). The Impact of Human Capital on Economic Growth. Procedia Economics and Finance, 22, 184-190. https://doi.org/10.1016/S2212-5671(15)00258-0

Pesaran, M. H., \& Shin, Y. (1999). An Autoregressive Distributed Lag Modelling Approach to Cointegration Analysis. In S. Storm (Ed.), Econometrics and Economic Theory in the 20th Century: The Ragnar Frisch Centennial Symposium (pp. 1-33). Cambridge University Press.

Piabuo, S., \& Tieguhong, J. C. (2017). Health Expenditure and Economic Growth-A Review of the Literature and an Analysis between the Economic Community for Central African States (CEMAC) and Selected African Countries. Health Economic Review, 7, Article No. 23. https://doi.org/10.1186/s13561-017-0159-1

Römer, P. M. (1990). Human Capital and Growth: Theory and Evidence. CarnegieRochester Conference Series on Public Policy, 32, 251-286. https://doi.org/10.1016/0167-2231(90)90028-J

Sahnoun, M. (2018). Does Health Expenditure Increase Economic Growth: Evidence from Tunisia. Romanian Economic Journal, Department of International Business and Economics from the Academy of Economic Studies Bucharest, 21, 126-144.

Samarasinghe, T. (2018). Impact of Governance on Economic Growth. MPRA Paper 89834, University Library of Munich.

Sarpong, B., Nketiah-Amponsah, E., \& Owoo, N. (2018). Health and Economic Growth Nexus: Evidence from Selected Sub-Saharan African (SSA) Countries. Global Business Review, 21, 1-20. https://doi.org/10.1177/0972150918778966

Sharma, P. (2019). Role of Human Capital in Economic Growth: A Comparative Study of India and China. https://doi.org/10.2139/ssrn.3319224

Silajdzic, S., \& Mehic, E. (2015). Knowledge Spillovers, Absorptive Capacities and the Impact of FDI on Economic Growth: Empirical Evidence from Transition Economies. Procedia-Social and Behavioral Sciences, 195, 614-623. https://doi.org/10.1016/j.sbspro.2015.06.142

Sokang, K. (2018). The Impact of Foreign Direct Investment on the Economic Growth in Cambodia: Empirical Evidence. International Journal of Innovation and Economic Development, 4, 31-38. https://doi.org/10.18775/ijied.1849-7551-7020.2015.45.2003

Sunde, T. (2017). Education Expenditure and Economic Growth in Mauritius: An Application of the Bounds Testing Approach. European Scientific Journal, 13, 70-81. https://doi.org/10.19044/esj.2017.v13n22p70

Tamura, R. (1991). Income Convergence in an Endogenous Growth Model. Journal of Political Economy, 99, 522-540. https://doi.org/10.1086/261765

Toda-Yamamoto (1995). Dynamic Granger Causality Test.

Udeorah, S. A., Obayori, J. B., \& Onuchuku, O. (2018). Health Care Expenditure and Economic Growth in Nigeria. International Journal of Research and Innovation in Social Science, 2, 33-36.

World Development Report (2016). Human Development for All. UNDP (United Nations Development Programme). 